\title{
Barriers to Corporate Social Responsibility: perceptions of a leading non- governmental organization
}

Diego Valério de Godoy Delmonico ${ }^{1}$, São Paulo State University, Bauru, São Paulo, Brazil

Hugo Henrique dos Santos², São Paulo State University, Bauru, São Paulo, Brazil

Octaviano Rojas Luiz ${ }^{3}$, São Paulo State University, Bauru, São Paulo, Brazil

João Victor Rojas Luiz ${ }^{4}$, São Paulo State University, Bauru, São Paulo, Brazil

Bárbara Stolte Bezerra ${ }^{5}$, São Paulo State University, Bauru, São Paulo, Brazil

Rosane Aparecida Gomes Battistelle ${ }^{6}$, São Paulo State University, Bauru, São Paulo, Brazil

\section{RESUMO}

Objetivo - Este artigo tem como objetivo identificar as principais barreiras ao desenvolvimento da Responsabilidade Social Corporativa (RSC) na visão de uma Organização Não Governamental (ONG) líder. A metodologia proposta avalia a importância atribuída a diferentes classes de barreiras à RSE a partir de uma perspectiva privilegiada de uma ONG brasileira.

Arcabouço teórico - Esta pesquisa se fundamentou na teoria vigente de barreiras às iniciativas de RSC e de tomada de decisão multicritério.

Metodologia - O método Analytic Hierarchy Process (AHP) foi utilizado para a avaliação e priorização das barreiras à RSE por meio da opinião de especialistas. A estabilidade da classificação foi testada por análise de sensibilidade dos pesos atribuídos.

Resultados - Os resultados indicam que a principal barreira é a falta de comprometimento da alta administração. Em contraste, as barreiras menos determinantes foram a falta de auditoria social, diversidade e consciência do cliente.

Contribuições - $\mathrm{O}$ artigo contribui estendendo a aplicação dos métodos de tomada de decisão multicritério à RSC e avaliando a importância relativa das barreiras. Este estudo também oferece resultados empíricos que ampliam a discussão sobre as barreiras à responsabilidade social, orientando gestores e tomadores de decisão que lideram iniciativas de RSC nas organizações a entender quais barreiras devem ser superadas e onde despender esforços gerenciais para isso. Palavras-chave - Analytic hierarchy process; Tomada de decisão multicritério; RSC; Organizações nãogovernamentais; Desenvolvimento sustentável.

\section{ABSTRACT}

Purpose - This paper aims to identify the main barriers to the development of Corporate Social Responsibility (CSR) in the view of a leading Non-governmental Organization (NGO). The proposed methodology evaluates the importance attached to different classes of barriers to CSR from a privileged perspective of a Brazilian NGO.

Theoretical framework - This research was based on the current theory of barriers to CSR initiatives and multicriteria decision making.

Design/methodology/approach - The Analytic Hierarchy Process (AHP) method was used for the assessment and prioritization of barriers to CSR through expert opinion. Ranking stability was tested by sensitivity analysis of the assigned weights.

Findings - The results indicate that the main barrier is the lack of top management commitment. By contrast, the least determinant barriers were the lack of social auditing, diversity, and customer awareness.

Originality/value - The article contributes by extending the application of multiple-criteria decision-making methods to CSR and evaluating the relative importance of the barriers. This study also offers empirical results that extend the discussion on barriers to social responsibility, guiding managers and decision makers who lead CSR initiatives in organizations to understand which barriers should be overcome, and where to spend managerial effort on.

Keywords - Analytic hierarchy process; Multicriteria decision making; CSR; Non-governmental organizations; Sustainable development.

1. Av. Engenheiro Luiz Edmundo Carrijo Coube, 14-01. PO BOX 17033-360, Bauru, São Paulo, Brazil, diego.monico@unesp.br, https://orcid.org/0000-0001-5268-190X; 2. hugo.santos@unesp.br, https://orcid.org/0000-0003-1366-3615; 3. octaviano.rojas@unesp.br, https://orcid.org/0000-0002-8994-589X; 4. joao.rojas@unesp.br, https://orcid.org/0000-0001-5641-9888; 5. barbara.bezerra@unesp.br, https://orcid.org/0000-0002-8459-4664; 6. rosane.battistelle@unesp.br, https://orcid.org/0000-0002-6958-7714.

DELMONICO, D.V.G.; SANTOS, H.H.; LUIZ, O.R.; LUIZ, J.V.R.; BEZERRA, B.S.; BATTISTELLE, R.A.G. Barriers to Corporate Social Responsibility: perceptions of a leading non-governmental organization GEPROS. Gestão da Produção, Operações e Sistemas, v.15, ${ }^{\circ}$ 4, p. $01-22,2020$. 


\section{INTRODUCTION}

Corporate Social Responsibility (CSR) is one of the most relevant subjects in the debate of the corporate role in society (ZIENTARA, 2017). There is no consensus on how CSR can be defined, and its definitions are explained from several dimensions (DAHLSRUD, 2008). Despite there is no univocal definition, CSR is defined as the continuous commitment of companies to behave ethically and to contribute to economic development while improving the quality of life of their workers, their families, and their community and society (HOLME; WATTS, 2000; WATTS; HOLME, 1999).

The North American society was one the pioneers to express social concerns about business practices (HEALD, 1957). The initial milestone is commonly assumed to be Bowen's work "Social Responsibilities of a Businessman", which is one of the firsts studies from an academic perspective about the social responsibility of entrepreneurs (BOWEN, 1953). Carroll (1999) studied the evolution of CSR. The author argues that Bowen's work marked the most serious debate on the topic in the 1950s. Since then, researchers in the 1960s developed studies aimed at deepening and clarifying the subject, which was not well established back then. In the beginning of the 1970s the variety of definitions and perspectives about CSR increased, along with a reinforcement of the economic dimension of social responsibility (DE BAKKER; GROENEWEGEN; DEN HOND, 2005).

The literature on social responsibility has expanded and included the assessment of barriers to its agenda. The state-of-art comprises literature reviews on barriers to CSR (AGUDO-VALIENTE; GARCÉS-AYERBE; SALVADOR-FIGUERAS， 2017). Other studies on barriers include a more empirical approach, involving their evaluation from case studies (DE TIENNE; LEWIS, 2005). Another empirical research involved a survey with top managers of Indian companies, which are part of the Global Compact, United Nations pact to encourage businesses worldwide to adopt sustainable and socially responsible policies (AREVALO; ARAVIND, 2011).

Research on barriers to CSR implementation are commonly focused on industryspecific companies, such as airline industry (KUO et al., 2016), manufacturing (GOYAL; KUMAR, 2017), and shipping (YUEN; LIM, 2016). Furthermore, there are studies about barriers to CSR in supply chains (FAISAL, 2010), in small and medium enterprises (CAMPIN; BARRAKET; LUKE, 2013; LAUESEN, 2011; SWEENEY, 2007) or related to 
the implementation of norms for social responsibility, e.g. ISO 26000 (DEUS; SELES; VIEIRA, 2014). In addition, the literature presents a theorization about ideological barriers to ethical CSR initiatives (NWOKE, 2017). Other studies address specific types of CSR barriers, such as behavioral barriers (GARAVAN et al., 2010) and obstacles to the internationalization process (LAUDAL, 2011).

Shen, Govindan and Shankar (2015) evaluate barriers to CSR using a multiple criteria decision making (MCDM) approach. The authors raised barriers to CSR implementation based on the opinion of experts. Even though the mentioned study focused on textile sector, the present research assesses the prioritization of barriers from the perspective of a Nongovernmental Organization (NGO) that mobilizes, sensitizes and helps companies make their management more socially responsible.

This present research sought to complement and confirm in a significantly different reality what previous research with a similar scope found. For example, Shen, Govindan and Shankar (2015) specifically analyze the Indian textile sector, while our article incorporates other economic sectors, including the services sector, expanding the scope in the study of barriers to corporate social responsibility initiatives.

Although the present analysis tackles the same problem addressed by the authors cited, originality in research means the production of new knowledge, which includes testing the results of previous research under new conditions and sources of evidence. Shen, Govindan and Shankar (2015) suggest that data should be collected and analyzed in different locations. In addition, these authors recommend consulting decision makers with different backgrounds.

In addition to these distinctions in scope, we can mention differences in terms of the results obtained and the methods used. While the results of Shen, Govindan and Shankar (2015) pointed out financial constraints as the main barrier, ours present the lack of commitment from top management as the main barrier to the adoption of social responsibility initiatives, which may indicate a difficulty in generalizing main barriers to different contexts.

Significant methodological contrasts are identified between the present research and that of Shen, Govindan and Shankar (2015). We tested a new model composed of four hierarchical levels, grouping barriers in broader constructs. This new classification of barriers to the implementation of CSR (political/demographical, informational and organizational) allowed an integrated analysis of multicriteria decision making for different dimensions of barriers. Another original contribution of the work is the performance of sensitivity analysis 
to assess the stability of the results obtained, ensuring greater robustness to the rankings found.

CSR actions have been proliferating in developing countries and this phenomenon has not been fully understood (HILSON; HILSON; DAUDA, 2019). The studied NGO has its activities in Brazil, an emerging country ranked among the worst in relation to institutional transparency (TRANSPARENCY INTERNATIONAL, 2019). Brazil has been the scenario of debates on the subject of social responsibility (PENA, 2014), including its role in its institutional development (GRIESSE, 2007). In addition, the Brazilian Association of Technical Standards (ABNT) supported the elaboration of ISO 26000, a set of guidelines for social responsibility. Brazil holds approximately 5.89\% of the 12,837 companies signatories to the Global Compact (UN GLOBAL COMPACT, 2020), which demonstrates the Brazilian relevance in the international initiative. Despite this Brazilian importance for the development of the field, Egri and Ralston (2008) indicate that there are few studies in the Latin American context.

The literature has explicit the influential role of NGOs in disseminating and supporting social issues in the corporate environment. For example, the integrated action of NGOs can lead to greater CSR support (DOH; GUAY, 2006). There is also evidence that a better CSR performance can increase NGO confidence in a company (DEN HOND et al., 2014).

More objective analysis of perceptual aspects regarding the level of importance of each barrier to CSR is required. For example, research on barriers to CSR have been published (AGUDO-VALIENTE; GARCÉS-AYERBE; SALVADOR-FIGUERAS, 2017; AREVALO; ARAVIND, 2011; NWOKE, 2017) but only one uses MCDM methods (SHEN; GOVINDAN; SHANKAR, 2015), that has the potential to give robustness to CSR barriers analysis (BISWAS; GARG; SINGH, 2017). This article meets the demand for studies on Latin America by using an organization with privileged position to evaluate the most relevant barriers for CSR. Furthermore, this research applies a well-established MCDM method, following procedures of previous research (DELMONICO et al., 2018; DOS SANTOS; MÁXIMO DE SOUZA; SOUZA ARAGÃO, 2018; GOVINDAN et al., 2014).

Thus, the aim of the present research is to identify the main barriers to the development of CSR in the perspective of a leading NGO. To achieve this objective, the Analytic Hierarchy Process (AHP) method was used for the evaluation of barriers to CSR. The variables used are based on the literature. The main contribution of this research is to 
develop a framework for measuring the barriers to CSR, which would allow practitioners to identify and concentrate efforts to overcome critical challenges. This study also can be applied to different contexts, enabling comparisons between different organizations, sectors and scenarios.

\section{THEORETICAL FOUNDATION}

The main barriers to the implementation of CSR were selected from the literature, in order to support the multicriteria methodology. A barrier in this article is understood as any factor, initiative or condition that hinders or even prevents an implementation from occurring at its maximum potential (both in terms of effectiveness and efficiency). This definition was based on earlier works with similar objectives (AREVALO; ARAVIND, 2011; DE TIENNE; LEWIS, 2005; FAISAL, 2010).

The work of Shen, Govindan and Shankar (2015) studied barriers in textile industry context. The barriers listed by Shen, Govindan and Shankar (2015) were based on Baskaran, Nachiappan and Rahman (2011) and Valmohammadi (2011). However, Shen, Govindan and Shankar (2015) considered only one hierarchy level, and compared all barriers under the same conditions without dividing them into groups according to their characteristics.

For the purpose of this paper, the barriers were divided into three categories: political and demographic, informational, and organizational barriers. Political and demographic barriers involves institutional restraints, including regulatory issues and lack of a well-defined CSR policy (KANGAS; LAZAREVIC; KIVIMAA, 2018). This category also comprises demographic barriers. For instance, the social and demographic profile of each region guides and restricts the behavior of individuals and institutions (CAMPION, 2018).

In turn, informational barriers are related to the lack of knowledge and information relevant to CSR implementation (RAUCH; CASELLA, 2003), as well as lack of awareness and concern with environmental and social issues (DIXON-O'MARA; RYAN, 2018; MILBRATH, 1995). The literature also cites informational barriers as one of the main problems in generating pro-sustainability behavior (JUVAN; DOLNICAR, 2014) and environmental improvements (KOSTKA; MOSLENER; ANDREAS, 2013; RAI; BECK, 2017).

Lastly, organizational barriers are internal to the organization, considering factors such as employee attitude, inadequate top management leadership, obsolete management practices 
and uncertainty on the expected results (JABBOUR et al., 2018). The lack of managerial attention directed to sustainability issues is also pointed out as relevant to CSR adoption (KOSTKA; MOSLENER; ANDREAS, 2013). Within an organization, the power structure can impact on decisions. If decision makers have no power within the organization, this can hinder improvements (KANGAS; LAZAREVIC; KIVIMAA, 2018).

In the present article, four hierarchical levels were considered, in order to reduce the number of comparisons and facilitate the decision-making process. The barriers and their respective explanations are shown in Table 1.

Table 1 - Description and sources of barriers to CSR.

\begin{tabular}{|c|c|c|}
\hline Barriers & Description & Sources \\
\hline \multicolumn{3}{|c|}{ Political and Demographic } \\
\hline $\begin{array}{l}\text { Lack regulations and } \\
\text { standards (PD1) }\end{array}$ & $\begin{array}{l}\text { Developing countries do not have clear laws and } \\
\text { standards on CSR practices. }\end{array}$ & $\begin{array}{l}\text { (DUARTE; RAHMAN, } \\
\text { 2010) }\end{array}$ \\
\hline $\begin{array}{l}\text { Lack social auditing } \\
\text { (PD2) }\end{array}$ & $\begin{array}{l}\text { Failure to carry out a social audit is an obstacle. } \\
\text { Companies do not feel pressured to comply with CSR } \\
\text { measures. }\end{array}$ & $\begin{array}{l}\text { (DUARTE; RAHMAN, } \\
\text { 2010) }\end{array}$ \\
\hline Diversity (PD3) & $\begin{array}{l}\text { CSR varies according to each region, country, or } \\
\text { legislation. Such diversity prevents managers from } \\
\text { understanding how to implement CSR in companies. }\end{array}$ & $\begin{array}{l}\text { (DUARTE; RAHMAN, } \\
\text { 2010) }\end{array}$ \\
\hline \multicolumn{3}{|l|}{ Informational } \\
\hline Lack of information (I1) & $\begin{array}{l}\text { Since there is no consensus around a single CSR } \\
\text { definition, the lack of information on the subject } \\
\text { presents challenges for companies to implement it. }\end{array}$ & $\begin{array}{l}\text { (DUARTE; RAHMAN, } \\
2010 ; \\
\text { VALMOHAMMADI, } \\
2011 \text { ) }\end{array}$ \\
\hline Lack of knowledge (I2) & $\begin{array}{l}\text { Due to the lack of information, CSR practices are } \\
\text { poorly understood in organizations, which limits its } \\
\text { effectiveness in the long run and hinders subsequent } \\
\text { projects. }\end{array}$ & $\begin{array}{l}\text { (BATTAGLIA } \text { et al., } \\
\text { 2010; DUARTE; } \\
\text { RAHMAN, 2010; } \\
\text { VALMOHAMMADI, } \\
\text { 2011) }\end{array}$ \\
\hline $\begin{array}{l}\text { Lack stakeholder } \\
\text { awareness (I3) }\end{array}$ & $\begin{array}{l}\text { As stakeholders do not see the importance of } \\
\text { implementation, they do not provide the necessary } \\
\text { support, in terms of resources and knowledge. }\end{array}$ & $\begin{array}{l}\text { (DUARTE; RAHMAN, } \\
2010 \text {; } \\
\text { VALMOHAMMADI, } \\
\text { 2011) }\end{array}$ \\
\hline $\begin{array}{l}\text { Lack of client awareness } \\
\text { (I4) }\end{array}$ & $\begin{array}{l}\text { Lack of pressure from the consumer market on } \\
\text { sustainability aspects, especially when the customer's } \\
\text { focus is on costs. }\end{array}$ & $\begin{array}{l}\text { (DUARTE; RAHMAN, } \\
2010 ; \\
\text { VALMOHAMMADI, } \\
\text { 2011) }\end{array}$ \\
\hline Lack of training (I5) & $\begin{array}{l}\text { Little or no training of managers and other employees } \\
\text { about CSR practices for correct and strategic } \\
\text { deployment. }\end{array}$ & $\begin{array}{l}\text { (BASKARAN; } \\
\text { NACHIAPPAN; } \\
\text { RAHMAN, 2011; } \\
\text { DUARTE; RAHMAN, }\end{array}$ \\
\hline
\end{tabular}


2010)

\begin{tabular}{lll}
\hline Organizational & & \\
\hline $\begin{array}{l}\text { Financial constraints } \\
(\mathrm{O} 1)\end{array}$ & $\begin{array}{l}\text { The high initial cost for the implementation of CSR } \\
\text { initiatives is an obstacle experienced by the } \\
\text { companies. }\end{array}$ & $\begin{array}{l}\text { (BASKARAN; } \\
\text { NACHIAPPAN; } \\
\text { RAHMAN, 2011; } \\
\text { DUARTE; RAHMAN, } \\
\text { 2010) }\end{array}$ \\
$\begin{array}{l}\text { Lack of top } \\
\text { management } \\
\text { commitment }(\mathrm{O} 2)\end{array}$ & Only financial benefits are taken into account. & $\begin{array}{l}\text { (DUARTE; RAHMAN, } \\
\text { 2010) }\end{array}$ \\
$\begin{array}{ll}\text { Corporate culture (O3) } \\
\text { Some companies are resistant to change their } \\
\text { strategies and adopt CSR. }\end{array}$ & $\begin{array}{l}\text { (DUARTE; RAHMAN, } \\
\text { 2010) }\end{array}$ \\
$\begin{array}{l}\text { Small and medium-sized companies are not aware of } \\
\text { adopting CSR initiatives and therefore are not } \\
\text { motivated to take such actions. }\end{array}$ & $\begin{array}{l}\text { (DUARTE; RAHMAN, } \\
\text { 2010) }\end{array}$ \\
\hline
\end{tabular}

Source: The authors (2020).

\section{METHODOLOGICAL PROCEDURES}

This research can be classified as quantitative and exploratory. The method employed to assess the barriers on CSR through expert opinion was AHP. AHP is a MCDM method used to obtain priorities from personal judgments through a set of paired comparisons. The comparisons are done according to some decision criterion and the judgments are done through distinct intensities of importance. Mathematical simplicity and flexibility make AHP a powerful mathematical tool for decision making, with applications in the most varied areas (SIPAHI; TIMOR, 2010).

The chosen NGO currently has 387 associated companies, with annual revenues totaling around 35\% of Brazilian Gross Domestic Product (GDP). These 387 companies were not consulted directly in this survey, only being part of the NGO partnership network. Since its foundation, this organization has leaded the promotion of CSR in Brazil. These facts indicate the international relevance of the organization's work in the development of ethical business relationships, being an essential component of the CSR governance structure (PEÑA, 2014). This means that the focused organization has a privileged view of the field that can contribute to research evaluation and decision-making process required by AHP method. NGOs have an important role in supporting the implementation of CSR initiatives in companies, mainly in emerging countries (GUAY; DOH; SINCLAIR, 2004). According to 
these authors, many companies do not have the specific resources and knowledge to carry out an effective CSR implementation, needing to invest in training for their employees and hire specific labor for the implementation. Partnership with NGOs can be an alternative to enable implementations under the conditions described. Still, the view that NGOs have of the obstacles that restrict the adoption of socially responsible practices presents significant differences in relation to the perspective of traditional businesses (BRAND; BLOK; VERWEIJ, 2020), a point that was not specifically addressed in the CSR literature.

After selecting the respondent organization, the NGO's institutional website was accessed, in order to obtain the company's email address. An initial contact was made through e-mail to the company's communications department. The purpose of the survey was described to the communications department, which appointed a specialist responsible for completing the survey instrument. The specialist (the decision maker for the application of the AHP) was the manager of interinstitutional relations. The position of the specialist was adequate to responding since he acts as an intermediary with the various CSR implementation projects with the members of the NGO. Data collection took place asynchronously by sending the questionnaire and receiving the completed instrument by e-mail. The responses were analyzed for consistency as required by the AHP method, which will be detailed later in this section. The level of consistency was adequate (less than $10 \%$ of inconsistency) and there was no need for additional rounds of responses to achieve the recommended level.

AHP is an approach that assists in the organization, decomposition and analysis of complex problems. The AHP requires a hierarchical structure composed of levels with elements to be compared with each other, in order to assign weights and prioritize these elements (DA SILVA WEGNER et al., 2018). The hierarchy structure used in this research is shown in Figure 1. In level 2, the barriers are divided in three categories: Political and Demographic (PD), which was divide in three subcategories (level 3); Informational (I), which was divide in five subcategories (level 3); Organizational $(\mathrm{O})$, which was divide in four subcategories (level 3). 
Figure 1 - AHP structure for identifying barriers to the implementation of CSR practices.

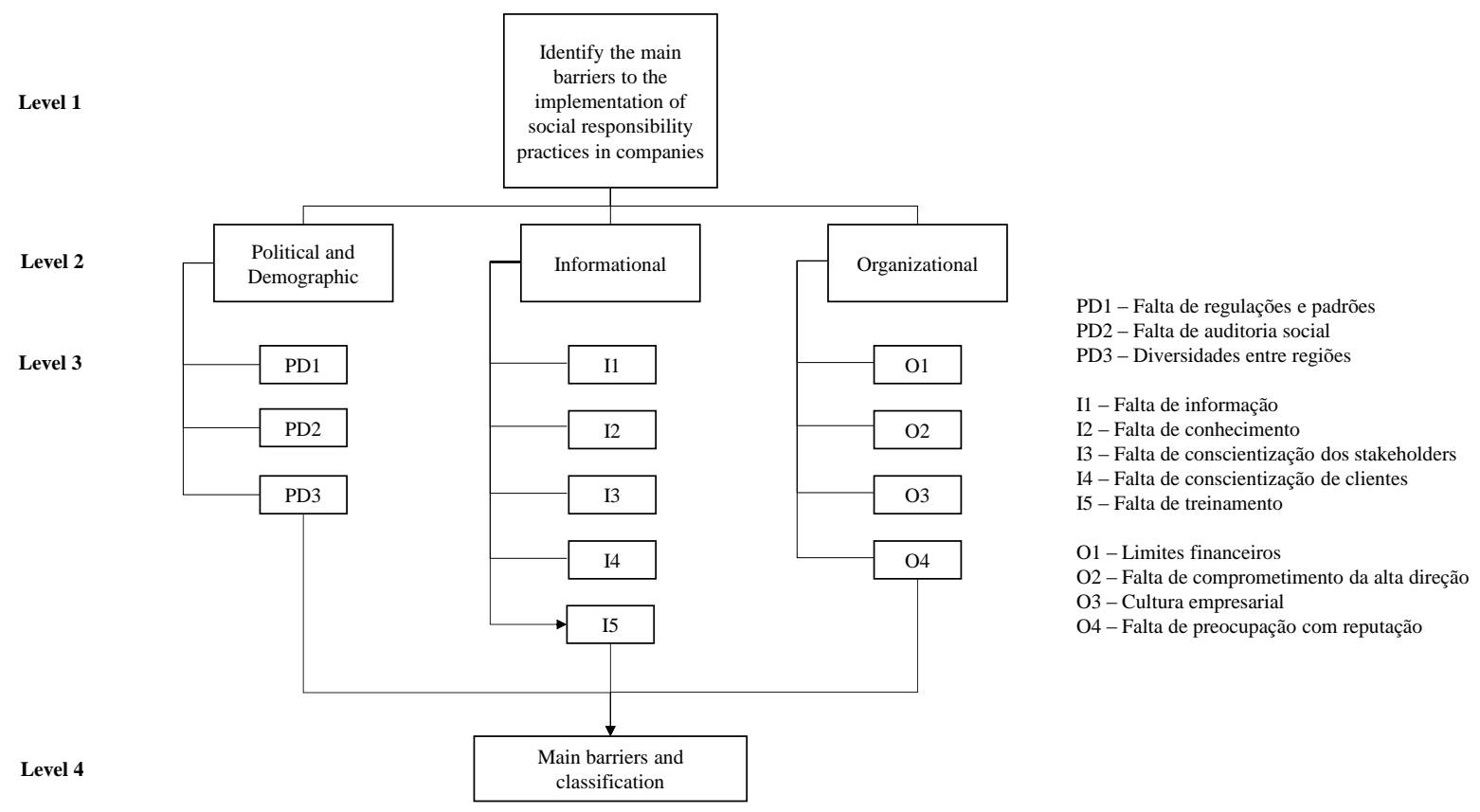

Source: The authors (2020).

From this structure, it is possible to carry out paired comparisons between the types of barriers (level 2) and between the specific barriers within each class (level 3). These comparisons were collected using a research instrument detailed in the following section.

\subsection{Comparisons by AHP method and questionnaire application}

After structuring the hierarchy, paired comparisons must be made. Two criteria of a lower level are compared to the level above. With this, the decision maker makes his judgment about the degree of importance of one criterion regarding the other (HO, 2008). The Saaty scale (SAATY, 1990), shown in Table 2, is used to perform the comparisons.

Table 2 - Saaty's fundamental scale.

\begin{tabular}{llr}
\hline $\begin{array}{l}\text { Intensity of } \\
\text { Importance }\end{array}$ & Definition & Explanation \\
\hline 1 & Equal importance & Two activities contribute equally to the goal. \\
3 & Moderated & $\begin{array}{r}\text { Experience and judgment favor slightly one } \\
\text { activity over another. }\end{array}$ \\
5 & Tightly & $\begin{array}{c}\text { Experience and judgment strongly favors or } \\
\text { essentially one activity relative to another. } \\
\text { One activity is strongly favored over another and } \\
\text { its mastery demonstrated in practice. }\end{array}$
\end{tabular}


9

Extremely

$2,4,6,8$
Evidence favoring one activity over another is of the highest possible degree of affirmation. preferences listed above.

Source: Saaty (1990).

With the judgments done, the reciprocal decision matrices are constructed. Considering two criteria under analysis ( $\mathrm{A}$ and $\mathrm{B}$ ), if $\mathrm{A}$ is five times more important than $\mathrm{B}$, consequently, $\mathrm{B}$ is $1 / 5$ more important than $\mathrm{A}$. The calculation for modeling the reciprocal matrix is presented in Equation 1.

$$
\mathrm{Aw}=\left[\begin{array}{cccc}
1 & a_{12} & \ldots & a_{1 n} \\
1 / a_{12} & 1 & \ldots & a_{2 n} \\
\vdots & \vdots & \vdots & \vdots \\
1 / a_{1 n} & 1 / a_{2 n} & \cdots & 1
\end{array}\right]
$$

To carry out the judgments required by the method, it was essential to use the opinion of a specialist with a broad vision about the field, which was not limited to the perspective adopted by one or another business organization. For this, the focused organization was contacted, which, as already mentioned, is recognized in promoting social responsibility in Brazil. Thus, the person designated to conduct the trials was a professional responsible for the institutional relations of the organization, with knowledge about the difficulties of companies to undertake social responsibility actions and the challenges of promoting a mentality focused on social responsibility in Brazil.

\subsection{Consistency Analysis}

One of the critical features of a decision-making method is to ensure that expert judgments are adequately coherent. According to Saaty (1990), the consistency ratio should obtain values lower than 0.10 . The consistency calculations are made from the equations 2 and 3.

$$
I C=\frac{\lambda_{\max }-n}{n-1}
$$

Where $\lambda_{\max }$ represents the eigenvalue of the matrix under analysis and $\mathrm{n}$ represents the order of the matrix. To calculate the consistency ratio, simply divide the CI value by the Random Index (RI) value, as presented in Equation 3. 


$$
R C=\frac{I C}{R I}
$$

The value of RI is tabulated and depends on the order of the matrix. The Table 3 shows the values according to its order.

Table 3 - Random Consistency Index values.

\begin{tabular}{ccccccccccc}
\hline $\mathbf{N}$ & 1 & 2 & 3 & 4 & 5 & 6 & 7 & 8 & 9 & 10 \\
\hline Random Index & 0 & 0 & 0.52 & 0.89 & 1.11 & 1.25 & 1.35 & 1.40 & 1.45 & 1.49 \\
\hline & & & & & & & & & & \\
Source: Saaty (1990).
\end{tabular}

If the calculations exceed the limit of 0.10 , the judgments should be reconsidered by the decision makers. However, recent studies argue that this limit should be reviewed, since decision makers often agree with the classification generated by the method, despite inconsistencies above the threshold (ISHIZAKA; SIRAJ, 2018).

After approval of consistency levels in all decision matrices, the local and global weightings of the AHP method are calculated, so the classification of the barriers can be defined. In the survey, the overall classification, considering all the specific barriers (Level 3 of the hierarchy), was considered. Subsequently, also a particular analysis on each category was addressed.

\section{RESULTS}

Based on the AHP methodology, the organizations' decision maker made the judgments, and the relative weight among each barrier category were obtained. The results are presented in Table 4.

Table 4 - Relative weights for barrier classes.

\begin{tabular}{ccccc}
\hline & $\begin{array}{c}\text { Political and } \\
\text { Demographic }\end{array}$ & Informational & Organizational & Weight \\
\hline Political and Demographic & 1 & $1 / 5$ & $1 / 7$ & $\mathbf{0 . 0 7 1 9}$ \\
Informational & 5 & 1 & $1 / 3$ & $\mathbf{0 . 2 7 9 0}$ \\
Organizational & 7 & 3 & 1 & $\mathbf{0 . 6 4 9 1}$ \\
\hline
\end{tabular}

Source: The authors (2020). 
From the application of equations 1 and 2, the level of inconsistency of the above matrix was 0.0559 , that is, below the 0.10 allowed by the AHP method. It is important to note that organizational barriers have a higher weight in the implementation of CSR practices. In turn, informational and political/demographic barriers did not present much significant weight in the analysis of the organization. The relative weights of the categories of barriers directly interfere in the general investigation of the problem, that is, the organizational barriers tend to present more significant weight in the general classification.

After calculating the relative weights of the categories, the next step of the method is the calculation of specific weights of each barrier. The specific weights of political and demographic, informational and organizational barriers are presented in Table 5, 6 and 7, respectively.

Table 5 - Weights for political and demographic barriers.

\begin{tabular}{ccccc}
\hline & PD1 & PD2 & PD3 & Weight \\
\hline PD1 & 1 & 3 & 5 & $\mathbf{0 . 6 5 8 6}$ \\
PD2 & $1 / 3$ & 1 & 1 & $\mathbf{0 . 1 8 5 2}$ \\
PD3 & $1 / 5$ & 1 & 1 & $\mathbf{0 . 1 5 6 1}$ \\
\hline
\end{tabular}

Source: The authors (2020).

Table 6 - Weights for informational barriers.

\begin{tabular}{ccccccc}
\hline & I1 & I2 & I3 & I4 & I5 & Weight \\
\hline I1 & 1 & 1 & 3 & 3 & 3 & $\mathbf{0 . 3 3 9 0}$ \\
I2 & 1 & 1 & 1 & 3 & 3 & $\mathbf{0 . 2 7 2 1}$ \\
I3 & $1 / 3$ & 1 & 1 & 3 & $1 / 3$ & $\mathbf{0 . 1 4 0 8}$ \\
I4 & $1 / 3$ & $1 / 3$ & $1 / 3$ & 1 & $1 / 3$ & $\mathbf{0 . 0 7 2 8}$ \\
I5 & $1 / 3$ & $1 / 3$ & 3 & 3 & 1 & $\mathbf{0 . 1 7 5 3}$ \\
\hline
\end{tabular}

Source: The authors (2020).

Table 7 - Weights for organizational barriers.

\begin{tabular}{cccccc}
\hline & $\mathrm{O} 1$ & $\mathrm{O} 2$ & $\mathrm{O} 3$ & $\mathrm{O} 4$ & Weight \\
\hline $\mathrm{O} 1$ & 1 & $1 / 5$ & $1 / 3$ & 3 & $\mathbf{0 . 3 3 9 0}$ \\
$\mathrm{O} 2$ & 5 & 1 & 5 & 5 & $\mathbf{0 . 2 7 2 1}$ \\
$\mathrm{O} 3$ & 3 & $1 / 5$ & 1 & 1 & $\mathbf{0 . 1 4 0 8}$ \\
$\mathrm{O} 4$ & $1 / 3$ & $1 / 5$ & 1 & 1 & $\mathbf{0 . 0 7 2 8}$ \\
\hline \multicolumn{5}{l}{ Source: The authors $(2020)}$.
\end{tabular}

Source: The authors (2020). 
The consistency tests showed that all decision matrices presented adequate coherence. After that, the global weight is calculated, using the values of the relative weights of the barrier categories presented in Table 4 multiplied by the weights of the specific barriers in Table 5 to 7 . The global weight, as well as the final classification of the barriers, is shown in Table 8.

Table 8 - Global weights and barriers ranking.

\begin{tabular}{lccccc}
\hline Barrier Class & $\begin{array}{c}\text { AHP relative } \\
\text { weights }\end{array}$ & Barriers & $\begin{array}{c}\text { Relative weights } \\
\text { using AHP }\end{array}$ & $\begin{array}{c}\text { AHP Global } \\
\text { weights }\end{array}$ & Ranking \\
\hline Political and & 0.0719 & PD1 & 0.6586 & 0.0474 & 8 \\
Demographic & & PD3 & 0.1562 & 0.0112 & 12 \\
& & & & & \\
Informational & 0.2790 & I1 & 0.3390 & 0.0946 & 3 \\
& & I2 & 0.2721 & 0.0759 & 5 \\
& & I4 & 0.1408 & 0.0393 & 9 \\
& & I5 & 0.0728 & 0.0203 & 10 \\
& & O1 & 0.1753 & 0.0489 & 7 \\
Organizational & 0.6491 & O2 & 0.6191 & & \\
& & O3 & 0.1630 & 0.0804 & 4 \\
& & O4 & 0.0941 & 0.1058 & 2 \\
\hline
\end{tabular}

Source: The authors (2020).

The lack of commitment of the top management $(\mathrm{O} 2)$ was the barrier with greater weight in the analysis. The discrepancy of this barrier among the others indicates that this is the main problem for the implementation of social responsibility practices in Brazilian companies in the NGO perspective. The differences in relative weights between the categories of barriers allow a sensitivity analysis to be performed.

The sensitivity analysis has the purpose of testing the stability of the final ranking, varying the weights of the most prominent criterion in the analysis (CHANG et al., 2007; ISHIZAKA; LABIB, 2011), in this case, the weight of organizational barriers. With this, alternative classification scenarios can be elaborated, providing more information. In order to carry out the sensitivity analysis, the weight of the organizational barriers category was varied from 0.1 to 0.9 and the changes in the final ranking are shown in Table 9. 
Table 9 - Sensitivity analysis.

\begin{tabular}{ccccccccccccccc}
\hline \multicolumn{10}{c}{ New barriers weights generated by variations of organizational barrier global weight } \\
\hline Variation & PD1 & PD2 & PD3 & I1 & I2 & I3 & I4 & I5 & O1 & O2 & O3 & O4 \\
0.1 & 0.1216 & 0.0341 & 0.0287 & $\mathbf{0 . 2 4 2 6}$ & 0.1947 & 0.1008 & 0.0521 & 0.1254 & 0.0125 & 0.0620 & 0.0163 & 0.0095 \\
0.2 & 0.1081 & 0.0303 & 0.0255 & $\mathbf{0 . 2 1 5 7}$ & 0.1730 & 0.0896 & 0.0463 & 0.1115 & 0.0249 & 0.1239 & 0.0326 & 0.0189 \\
0.3 & 0.0946 & 0.0265 & 0.0223 & $\mathbf{0 . 1 8 8 7}$ & 0.1514 & 0.0784 & 0.0405 & 0.0975 & 0.0372 & 0.1858 & 0.0489 & 0.0283 \\
0.4 & 0.0810 & 0.0227 & 0.0192 & 0.1618 & 0.1298 & 0.0672 & 0.0347 & 0.0836 & 0.0496 & $\mathbf{0 . 2 4 7 7}$ & 0.0652 & 0.0377 \\
0.5 & 0.0675 & 0.0190 & 0.0160 & 0.1348 & 0.1082 & 0.0560 & 0.0289 & 0.0697 & 0.0620 & $\mathbf{0 . 3 0 9 6}$ & 0.0815 & 0.0471 \\
0.6 & 0.0540 & 0.0152 & 0.0128 & 0.1078 & 0.0865 & 0.0448 & 0.0231 & 0.0557 & 0.0743 & $\mathbf{0 . 3 7 1 5}$ & 0.0978 & 0.0565 \\
0.7 & 0.0405 & 0.0114 & 0.0096 & 0.0809 & 0.0649 & 0.0336 & 0.0174 & 0.0418 & 0.0867 & $\mathbf{0 . 4 3 3 4}$ & 0.1141 & 0.0659 \\
0.8 & 0.0270 & 0.0076 & 0.0064 & 0.0539 & 0.0433 & 0.0224 & 0.0116 & 0.0279 & 0.0991 & $\mathbf{0 . 4 9 5 3}$ & 0.1304 & 0.0753 \\
0.9 & 0.0135 & 0.0038 & 0.0032 & 0.0270 & 0.0216 & 0.0112 & 0.0058 & 0.0139 & 0.1114 & $\mathbf{0 . 5 5 7 2}$ & 0.1467 & 0.0847 \\
\hline
\end{tabular}

Source: The authors (2020).

The results of the sensitivity analysis show that when the global weight of the category "organizational barriers" varies from 0.1 to 0.3 , the lack of information (I1) is the main barrier to CSR practices. From 0.4 onwards, the lack of commitment of the top management takes the first position in the final classification. The analysis shows that organizational barriers have a high impact on the implementation of social responsibility practices. If such barriers are eliminated from the companies, there is a great possibility of improving the implementation of these practices.

\section{DISCUSSION}

Organizational barriers were the most decisive, followed by informational barriers, both considerably more important than political and demographic ones. The high importance of these two barriers related to the top management suggests that special attention should be given to leadership aspects, as evidenced by recent research (PETRENKO et al., 2016; REIMER; VAN DOORN; HEYDEN, 2018). The lack of commitment of top management $(\mathrm{O} 2)$, in the first position, can be related to the lack of concern for the company's reputation (O1). In addition, the high importance attributed to the barrier $\mathrm{O} 1$ confirms it as an important barrier to overcome, since the company's reputation is a determinant motivation for CSR implementation (AGUDO-VALIENTE; GARCÉS-AYERBE; SALVADOR-FIGUERAS, 2017). In addition, resistance in changing company strategies (DUARTE; RAHMAN, 2010) may be a plausible reason for the corporate culture to be the second most important barrier in 
the analysis. The application of new business strategies can cause higher costs for companies (SHEN; GOVINDAN; SHANKAR, 2015) and the financial impact has a direct relation with this barrier.

In the same way, other barriers of high importance, such as lack of information (I1) and lack of knowledge (I2) may, in some way, be related. Information barrier (I1) represents the difficulty of understanding the many conceptualizations and definitions regarding CSR. Such understanding can be achieved, among other ways, by adequate training in the promotion of social responsibility and business ethics. The lack of training and the difficult to access expert knowledge about the topic constitute the knowledge barrier (I2). This evidence is in line with what the literature on CSR training points out (ARIAS, 2008). All the mentioned facts also concern or have close relation to the corporate culture (O3) that occupies second place in the ranking. This confirms previous evidence pointing to significant relationships between organizational culture and CSR (KARASSIN; BAR-HAIM, 2016).

The least determinant barriers in the study were the lack of social auditing (PD2), diversity (PD3), and lack of customer awareness (I4). A remarkable feature in all of them is that they relate to the specific actions or characteristics of external stakeholders. These conclusions can be seen as a result of the voluntary nature of social responsibility (JAUERNIG; UHL; LUETGE, 2017), which is independent of auditing, consumer awareness, and regional variations. The least relevant informational barriers for the respondent were those related to consumer awareness (I4) and other stakeholders (I3). This result differs from previous evidence that indicates ideological divergence and lack of trust among stakeholders as important barriers to CSR (GORDON et al., 2012).

Differently from the study by Shen, Govindan and Shankar (2015), which pointed the financial constraints as the main barrier to the implementation of social responsibility practices, this research showed that the lack of commitment of top management is the main problem identified in Brazilian companies by the NGO expert. The financial constraints, another barrier characterized as organizational in this research, occupied the fourth place in the final classification. As in the research by Shen, Govindan and Shankar (2015), the financial constraints can be explained by the small size of most of the companies considered in the analysis. Financial issues are also pointed out as a considerable barrier in the study of Arevalo and Aravind (2011), but in this same study, the support of top management was not considered such a significant barrier in the analysis. 
Beyond what has been said, lack of CSR understanding, difficulties in interpreting the definition of social responsibility, and lack of senior management engagement in improving social responsibility practices are possible explanations for the lack of information barrier (I1) being the third in the general ranking. Lack of information is the only among informational barriers in the top three. Finally, lack of knowledge appears as the fifth most valuable barrier. Lack of information, aligned with the lack of training in CSR practices, results in lack of knowledge, making it difficult to adhere to these practices (LAPIN̦A; MAURĀNE; STARIN̦ECA, 2014).

The study of Jauernig, Uhl and Luetge (2017) on the impact of institutional structures suggests that some political and institutional barriers are negatively correlated with the likelihood of companies taking responsible actions. Also, Doh and Guay (2006) and Albareda, Lozano and Ysa (2007) present the influence of public policies for the solution of CSR problems, where NGO activism would have a significant impact. However, the results presented evidenced that political and demographic barriers are less relevant to the adoption of CSR in the Brazilian context in the NGO perspective. Thus, results suggest that professionals direct their efforts to overcome organizational and informational barriers and postpone actions to mitigate demographic and political obstacles.

\section{CONCLUSION}

This article aimed to investigate the most determinant barriers for CSR implementation. The findings suggest that, from the perspective of the NGO studied, the lack of top management commitment and lack of concern for reputation are the major barriers to social responsibility development. Another finding is that the lack of definitions regarding social responsibility is an expected problem for CSR implementation, especially with regard to human resources training. From a theoretical point of view, these results contribute to highlight the NGOs' particular view of leadership and knowledge aspects. Thus, this study contributes to the understanding of the relationship between NGOs and business and the role that institutional relations play in the implementation of CSR initiatives.

In addition, demographic barriers related to the attitudes of the external public were not perceived as a problem in this research. This perspective presented by the NGO is relevant, since this type of organization intermediates social actions between company and 
society. Future studies should focus on the role of other external stakeholders. The article contributes by extending the application of MCDM methods to the theme of social responsibility and the evaluation of the degree of importance of the barriers. In addition, the present study presented a different approach to the study of barriers, by classifying them into political and demographic, informational and organizational barriers. This integrated analysis of the aspects that impact the implementation of CSR initiatives allows the study of the interaction of the different dimensions involved in decision making, which would not be possible through an individualized analysis.

Besides, this study also offers empirical results that extend the discussion on barriers to social responsibility, and the findings of this research may guide managers and decision makers who lead CSR initiatives in organizations to understand which barriers should be overcome, and where to spend managerial effort on. The results can also guide public policies to stimulate CSR. This research also presents practical contributions for NGOs that intend to participate in CSR implementation projects, as they will be able to foresee which barriers are seen as priorities by this type of organization. Likewise, companies seeking consultancy or assistance with NGOs can use the results described here to plan these joint actions. Organizations can also adopt the AHP application steps exemplified in this article to perform specific analysis for their implementation projects. The AHP proved to be a method of easy application and interpretation, without great computational requirements and that allows analyzing the consistency of the manager's decision.

The limitations of this study include the fact that it was performed in a single organization. Even though, it is a relevant company in the national and international scenarios, which captures different visions in daily life, involving multiple relationships with many companies. It is emphasized that for the AHP method, one respondent is sufficient to achieve the objective of assessing perception, unlike regression analysis. It is not intended to generalize the results. The inclusion of other dimensions in the analysis, besides the variables selected from the literature, could complement the scope of this research. In addition, the studies used for the extraction of variables enjoy academic relevance in their field of study.

Future research could explain the mechanisms that lead the main barriers of this study to limit the results of CSR initiatives. In addition, future studies may prioritize solutions and practices that reduce or even eliminate the influence of the main barriers pointed out. 


\section{References}

AGUDO-VALIENTE, J.; GARCÉS-AYERBE, C.; SALVADOR-FIGUERAS, M. Corporate Social Responsibility Drivers and Barriers According to Managers' Perception; Evidence from Spanish Firms. Sustainability, v. 9, n. 12, p. 1821, 2017.

ALBAREDA, L.; LOZANO, J. M.; YSA, T. Public Policies on Corporate Social Responsibility: The Role of Governments in Europe. Journal of Business Ethics, v. 74, n. 4, p. 391-407, 2007.

AREVALO, J. A.; ARAVIND, D. Corporate social responsibility practices in India: approach, drivers, and barriers. Corporate Governance: The international journal of business in society, v. 11, n. 4, p. 399-414, 2011.

ARIAS, A. O. An interpretive systemic appraisal of corporate social responsibility and learning. Systems Research and Behavioral Science, v. 25, n. 3, p. 361-370, 2008.

BASKARAN, V.; NACHIAPPAN, S.; RAHMAN, S. Supplier assessment based on corporate social responsibility criteria in Indian automotive and textile industry sectors. International Journal of Sustainable Engineering, v. 4, n. 4, p. 359-369, 2011.

BATTAGLIA, M.; BIANCHI, L.; FREY, M; IRALDO, F. An innovative model to promote CSR among SMEs operating in industrial clusters: evidence from an EU project. Corporate Social Responsibility and Environmental Management, v. 17, n. 3, p. 133-141, 2010.

BISWAS, U. A.; GARG, S.; SINGH, A. Integrating analytic hierarchy process in corporate social responsibility measurement. International Journal of Operational Research, v. 29, n. 3, p. 317, 2017.

BOWEN, H. R. Social responsibility of the businessman. New York: Harper \& Row, 1953.

BRAND, T.; BLOK, V.; VERWEIJ, M. Stakeholder Dialogue as Agonistic Deliberation: Exploring the Role of Conflict and Self-Interest in Business-NGO Interaction. Business Ethics Quarterly, v. 30, n. 1, p. 3-30, 2020.

CAMPIN, S.; BARRAKET, J.; LUKE, B. Micro-Business Community Responsibility in Australia: Approaches, Motivations and Barriers. Journal of Business Ethics, v. 115, n. 3, p. 489-513, 2013.

CAMPION, E. D. The career adaptive refugee: Exploring the structural and personal barriers to refugee resettlement. Journal of Vocational Behavior, v. 105, p. 6-16, 2018.

CARROLL, A. B. Corporate Social Responsibility. Business \& Society, v. 38, n. 3, p. 268$295,1999$.

CHANG, C.-W.; WU, C.-R.; LIN, C.-T.; CHEN, H.-C. An application of AHP and sensitivity analysis for selecting the best slicing machine. Computers \& Industrial Engineering, v. 52, n. 2, p. 296-307, 2007. 
DA SILVA WEGNER, R.; GODOY, L. P.; SERPA, N. P.; MARTINELLI, M.; GODOY, T. P. Analytic Hierarchy Process (AHP) in the analysis of marketing mix in a construction material company. Revista Gestão da Produção, Operações e Sistemas, v. 13, n. 2, p. 299 $320,2018$.

DAHLSRUD, A. How corporate social responsibility is defined: an analysis of 37 definitions. Corporate Social Responsibility and Environmental Management, v. 15, n. 1, p. 1-13, 2008.

DE BAKKER, F. G. A.; GROENEWEGEN, P.; DEN HOND, F. A Bibliometric Analysis of 30 Years of Research and Theory on Corporate Social Responsibility and Corporate Social Performance. Business \& Society, v. 44, n. 3, p. 283-317, 2005.

DE TIENNE, K. B.; LEWIS, L. W. The pragmatic and ethical barriers to corporate social responsibility disclosure: The Nike case. Journal of Business Ethics, v. 60, n. 4, p. 359-376, 2005.

DELMONICO, D. V. G.; DOS SANTOS, H. H.; PINHEIRO, M. A. P.; CASTRO, R.; SOUZA, R. M. Waste management barriers in developing country hospitals: Case study and AHP analysis. Waste Management \& Research, v. 36, n. 1, p. 48-58, 2018.

DEN HOND, F.; REHBEIN, K. A.; DE BAKKER, F. G. A.; KOOIJMANS-VAN LANKVELD, H. Playing on Two Chessboards: Reputation Effects between Corporate Social Responsibility (CSR) and Corporate Political Activity (CPA). Journal of Management Studies, v. 51, n. 5, p. 790-813, 2014.

DEUS, R. M. DE; SELES, B. M. R. P.; VIEIRA, K. R. O. Organizations and ISO 26000: Review of concepts, motivators, and barriers to implementation. Gestão \& Produção, v. 21, n. 4, p. 793-809, 2014.

DIXON-O'MARA, C.; RYAN, L. Energy efficiency in the food retail sector: barriers, drivers and acceptable policies. Energy Efficiency, v. 11, n. 2, p. 445-464, 2018.

DOH, J. P.; GUAY, T. R. Corporate Social Responsibility, Public Policy, and NGO Activism in Europe and the United States: An Institutional-Stakeholder Perspective. Journal of Management Studies, v. 43, n. 1, p. 47-73, 2006.

DOS SANTOS, H. H.; MÁXIMO DE SOUZA, R.; SOUZA ARAGÃO, A. Decision analysis in referrals of children and adolescent victims of violence: An ANP approach. Journal of the Operational Research Society, v. 69, n. 9, p. 1483-1492, 2018.

DUARTE, F.; RAHMAN, S. Perceptions of corporate social responsibility by Bangladeshi managers: an exploratory study. International Review of Business Research Papers, v. 6, n. 5, p. 119-136, 2010.

EGRI, C. P.; RALSTON, D. A. Corporate responsibility: A review of international management research from 1998 to 2007. Journal of International Management, v. 14, n. 4, p. 319-339, 2008. 
FAISAL, M. N. Analysing the barriers to corporate social responsibility in supply chains: an interpretive structural modelling approach. International Journal of Logistics-Research and Applications, v. 13, n. 3, p. 179-195, 2010.

GARAVAN, T. N.; HERATY, N.; ROCK, A.; DALTON, E. Conceptualizing the behavioral barriers to CSR and CS in organizations: A typology of HRD interventions. Advances in Developing Human Resources, v. 12, n. 5, p. 587-613, 2010.

GORDON, M.; LOCKWOOD, M.; VANCLAY, F.; HANSON, D.; SCHIRMER, J. Divergent stakeholder views of corporate social responsibility in the Australian forest plantation sector. Journal of Environmental Management, v. 113, p. 390-398, 2012.

GOVINDAN, K.; KALIYAN, M; KANNAN, D.; HAQ, A. N. Barriers analysis for green supply chain management implementation in Indian industries using analytic hierarchy process. International Journal of Production Economics, v. 147, p. 555-568, 2014.

GOYAL, P.; KUMAR, D. Modeling the CSR barriers in manufacturing industries. Benchmarking: An International Journal, v. 24, n. 7, p. 1871-1890, 2017.

GRIESSE, M. A. The Geographic, Political, and Economic Context for Corporate Social Responsibility in Brazil. Journal of Business Ethics, v. 73, n. 1, p. 21-37, 2007.

GUAY, T.; DOH, J. P.; SINCLAIR, G. Non-governmental Organizations, Shareholder Activism, and Socially Responsible Investments: Ethical, Strategic, and Governance Implications. Journal of Business Ethics, v. 52, p. 125-139, 2004.

HEALD, M. Management's Responsibility to Society: The Growth of an Idea. Business History Review, v. 31, n. 04, p. 375-384, 1957.

HILSON, A.; HILSON, G.; DAUDA, S. Corporate Social Responsibility at African mines: Linking the past to the present. Journal of Environmental Management, v. 241, p. 340 $352,2019$.

HO, W. Integrated analytic hierarchy process and its applications - A literature review. European Journal of Operational Research, v. 186, n. 1, p. 211-228, 2008.

HOLME, R.; WATTS, P. Corporate Social Responsibility: Making Good Business Sense. World Business Council for Sustainable Development, 2000.

ISHIZAKA, A.; LABIB, A. Review of the main developments in the analytic hierarchy process. Expert Systems with Applications, v. 38, n. 11, p. 14336-14345, 2011.

ISHIZAKA, A.; SIRAJ, S. Are multi-criteria decision-making tools useful? An experimental comparative study of three methods. European Journal of Operational Research, v. 264, n. 2, p. 462-471, 2018.

JABBOUR, C. J. C.; JUGEND, D.; JABBOUR, A. B. L. S.; GOVINDAN, K.; KANNAN, D.; LEAL FILHO, W. "There is no carnival without samba": Revealing barriers hampering biodiversity-based R\&D and eco-design in Brazil. Journal of Environmental Management, 
v. 206, p. 236-245, 2018.

JAUERNIG, J.; UHL, M.; LUETGE, C. Voluntary agreements between competitors: trick or truth? Journal of Business Economics, v. 87, n. 9, p. 1173-1191, 2017.

JUVAN, E.; DOLNICAR, S. Can tourists easily choose a low carbon footprint vacation? Journal of Sustainable Tourism, v. 22, n. 2, p. 175-194, 2014.

KANGAS, H.-L.; LAZAREVIC, D.; KIVIMAA, P. Technical skills, disinterest and nonfunctional regulation: Barriers to building energy efficiency in Finland viewed by energy service companies. Energy Policy, v. 114, n. October 2016, p. 63-76, 2018.

KARASSIN, O.; BAR-HAIM, A. Multilevel corporate environmental responsibility. Journal of Environmental Management, v. 183, p. 110-120, 2016.

KOSTKA, G.; MOSLENER, U.; ANDREAS, J. Barriers to increasing energy efficiency: evidence from small-and medium-sized enterprises in China. Journal of Cleaner Production, v. 57, p. 59-68, 2013.

KUO, T. C.; OKUDAN KREMER, G. E.; PHUONG, N. T.; HSU, C.-W. Motivations and barriers for corporate social responsibility reporting: Evidence from the airline industry. Journal of Air Transport Management, v. 57, p. 184-195, 2016.

LAPIN̦A, I.; MAURĀNE, G.; STARIN̦ECA, O. Human Resource Management Models: Aspects of Knowledge Management and Corporate Social Responsibility. Procedia - Social and Behavioral Sciences, v. 110, p. 577-586, 2014.

LAUDAL, T. Drivers and barriers of CSR and the size and internationalization of firms. Social Responsibility Journal, v. 7, n. 2, p. 234-256, 2011.

LAUESEN, L. M. CSR in publicly owned enterprises: opportunities and barriers. Social Responsibility Journal, v. 7, n. 4, p. 558-577, 2011.

MILBRATH, L. W. Psychological, Cultural, and Informational Barriers to Sustainability. Journal of Social Issues, v. 51, n. 4, p. 101-120, 1995.

NWOKE, U. Corporations and development. International Journal of Law and Management, v. 59, n. 1, p. 122-146, 2017.

PEÑA, A. M. Rising Powers, Rising Networks: Brazilian Actors in Private Governance. Oxford Development Studies, v. 42, n. 2, p. 217-237, 2014.

PETRENKO, O. V.; AIME, F.; RIDGE, J.; HILL, A. Corporate social responsibility or CEO narcissism? CSR motivations and organizational performance. Strategic Management Journal, v. 37, n. 2, p. 262-279, 2016.

RAI, V.; BECK, A. L. Play and learn: Serious games in breaking informational barriers in residential solar energy adoption in the United States. Energy Research \& Social Science, v. 27, p. 70-77, 2017. 
RAUCH, J. E.; CASELLA, A. Overcoming Informational Barriers to International Resource Allocation: Prices and Ties. The Economic Journal, v. 113, n. 484, p. 21-42, 2003.

REIMER, M.; VAN DOORN, S.; HEYDEN, M. L. M. Unpacking Functional Experience Complementarities in Senior Leaders' Influences on CSR Strategy: A CEO-Top Management Team Approach. Journal of Business Ethics, v. 151, n. 4, p. 977-995, 2018.

SAATY, T. L. How to make a decision: The analytic hierarchy process. European Journal of Operational Research, v. 48, n. 1, p. 9-26, 1990.

SHEN, L.; GOVINDAN, K.; SHANKAR, M. Evaluation of barriers of corporate social responsibility using an analytical hierarchy process under a fuzzy environment-A textile case. Sustainability (Switzerland), v. 7, n. 3, p. 3493-3514, 2015.

SIPAHI, S.; TIMOR, M. The analytic hierarchy process and analytic network process: an overview of applications. Management Decision, v. 48, n. 5, p. 775-808, 2010.

SWEENEY, L. Corporate social responsibility in Ireland: barriers and opportunities experienced by SMEs when undertaking CSR. Corporate Governance: The international journal of business in society, v. 7, n. 4, p. 516-523, 2007.

TRANSPARENCY INTERNATIONAL. Corruption Perceptions Index 2018. Berlin, 2019.

UN GLOBAL COMPACT. Our Participants. Retrived from: https://www.unglobalcompact.org/what-is-gc/participants. 2020.

VALMOHAMMADI, C. Investigating corporate social responsibility practices in Iranian organizations: an ISO 26000 perspective. Business Strategy Series, v. 12, n. 5, p. 257-263, 2011.

WATTS, P.; HOLME, R. Corporate Social Responsibility: Meeting Changing Expectations. World Business Council for Sustainable Development, 1999.

YUEN, K. F.; LIM, J. M. Barriers to the Implementation of Strategic Corporate Social Responsibility in Shipping. The Asian Journal of Shipping and Logistics, v. 32, n. 1, p. 4957, 2016.

ZIENTARA, P. Socioemotional Wealth and Corporate Social Responsibility: A Critical Analysis. Journal of Business Ethics, v. 144, n. 1, p. 185-199, 2017. 